VS Publications

Alford Council of International English \& Literature Journal(ACIELJ)

Impact Factor:4.401(SJIF)An International Peer-Reviewed English Journal

www.acielj.com

Vol-3,Issue-2,2020

ISSN:2581-6500

\title{
TRAINING FOR TEACHERS OF ENGLISH SERVING IN ENGINEERING COLLEGES AND ITS IMPACT ON ENGLISH LANGUAGE TEACHING- LEARNING PROCESS
}

\author{
Mr. B. Sanyasi Rao ${ }^{1}$ \\ Research Scholar, JNTU, Kakinada, EG, Andhra Pradesh,India \\ Dr. G. Suvarna Lakshmi ${ }^{2}$ \\ Associate Professor \\ Dept. of ELT, SDE ,EFL University, Hyderabad,Telangana,India
}

\begin{abstract}
Teacher learning is continuous, and steady process. To accustom the advanced English language teaching methods and approaches, teachers of English must be up-to-date. Teacher Training promotes teachers' teaching skills and master new knowledge, eventually, it augments teachers' teaching proficiency. It in turn enhances students' learning potentiality. Proper Educational \& Professional Training must be received by the teachers to own sufficient teaching skills to dedicate themselves to advance teaching-learning process successfully well. A qualitative teacher training program makes the teachers generate positive environment in teaching-learning process. Teachers of English, serving in engineering colleges need to be trained to teach English the language to the Engineering Students. Without required teacher training, teachers of English struggle to impart language skills, consequently students struggle to acquire the targeted language.
\end{abstract}

Keywords: Teacher Training, Teaching Skills, Learning Potentiality, TeachingLearning Process, Teachers of English and Engineering Students
Introduction: This paper aims at the need of teacher training for the teachers of English, serving in engineering colleges. English language has gained unprecedented popularity across the globe for various reasons and purposes. Particularly if we look at Engineering Students, English is very critical for their professional Development throughout their lives. In the realm of engineering education, English language is a predominant factor as it is medium of instruction, to acquire subject knowledge from written material and to secure a job. English language is a necessary for an engineer, who aspires to carry out his/her professional practice in the global context (Reimer 2002). In this situation, it becomes even more critical for the teachers, who teach and train the students to be well-equipped with language skills. Hence, training the teachers of English has becomes an integral part of teaching English language.

Teaching Vs Training: Teaching and Training seem to be one in many a condition, and they are often misinterpreted but Training, strikingly different from teaching. Training is undertaking a particular skill to be 
VS Publications

Alford Council of International English \& Literature Journal(ACIELJ)

Impact Factor:4.401(SJIF)An International Peer-Reviewed English Journal

www.acielj.com

Vol-3,Issue-2,2020

ISSN:2581-6500

acquired through tutoring and mentoring.

Teaching is imparting knowledge on a particular realm and focuses on academics.

Training is a skill based learning, focusing more on practicality. Teaching is imparting subject-knowledge on a particular academic realm whereas Training is targeting a specific skill to be developed through instructions and practice (www.keydifferences.com). They seem to be alike and sometimes are used interchangeably but their roles are different. Teaching in nature is theoretical oriented whereas Training is practical oriented and more hands on. Teaching imparts subject-knowledge and information by the examples, perception or experience but Training is meant for acquiring abilities by the instructions and drills. For instance, if someone is taught how to drive a car, he/she may bag knowledge about driving a car, but the knowledge cannot make him/her drive a car.

Training uses the abstract knowledge to master over a skill. Training involves understanding basic concepts \& principles as an prerequisite for applying them to teaching and the ability to demonstrate principles and practices in the classroom. Teacher training also involves trying out new strategies in the classroom usually with supervision and monitoring, and getting feedback from other on his/her practice (Richards and Farrell 2005). Teaching imparts knowledge or information required to do a particular job. The perspective to understand and make the best use of the knowledge depends on Training. Teaching is more theoretical aspect of knowledge acquisition but training is more practical (www.keydifferencec.com) To teach is to understand but to train is to perform the task. Teaching is a long-term oriented process whereas Training is a short term goal oriented.

Importance of Teacher Training: Teachers have to be trained and supported like other professions. The compliance of Training is desired for bureaucrats, Engineers, doctors, scientists, and so on. However, we expect teachers to be blessed with an enormous passion and impart subject-knowledge with excellence. To upgrade the subject knowledge of the teachers, they must be allowed to participate in teacher training courses (Rayappa 2016). Teaching is important but Training for teachers is more important to better the Teaching-Learning Process. If the teachers are trained, students display more interest in the classroom teaching (Kunter et al. 2007). Dearth of Professional Training and Development of the teachers can cause dissatisfaction in the quality of their teaching in the classroom to design capable students with the required knowledge and skills in their respective subjects (Boudersa, Nassira 2016). If a teacher is trained. He makes the student more competent and confident in the area he deals with. Teachers' Training equips a teacher with positive attitude towards students, with updated knowledge and behavioral skills required in the classroom to execute the tasks successfully well in the classroom.

Mr. Prashar, Lead Academic Consultant at Educational Initiatives posted 'I have been privileged to interact 
VS Publications

Alford Council of International English \& Literature Journal(ACIELJ)

Impact Factor:4.401(SJIF)An International Peer-Reviewed English Journal

www.acielj.com

Vol-3,Issue-2,2020

ISSN:2581-6500

with many teachers, principals, parents, students and education management professionals across the country and almost all of them have unanimously expressed discontentment concerning the following pointers. They are: The quality of teachers has been deteriorating over time, there is immediate need of teachertraining programs and the one time erratic teacher training-program yields no good result in teaching-learning processes (Prashar Ghildyal 2016). A good teacher updates himself to inculcate interest in the students to learn by his effective teachinglearning Process. Franklin Benjamin said, "Tell me and I forget; teach me and I remember; involve me and I learn." Training targets learning by doing. Teaching imparts knowledge but Training shapes habits to transform into skill. Training on Classroom Management helps the teacher to understand the Students' Psychological Behavior.

It is an extremely important for a teacher to better his professional development. Teacher Training \& Classroom management are essential to both teachers' education and teachers' professional development, it is crucial to keep teachers' knowledge up-to-date. Hence, they can deliver high quality of teaching (Emmar \& Saborine 2015). Teachers are to be dynamic, but they do not ready made professionals. It is important to understand that a good teacher is always a student, who keeps on learning and making himself/herself updated. A special training program does not merely help the teachers what to do but it helps how to do and why to do. The Trained Teachers are aware of presenting pre-learning material, following up the process and eventually bridges the gap between what they have learnt, and what they are going to teach. Quality of a teacher is a significant factor in determining benefits in students' accomplishment (Guerriero 2016). Training programs equip the teachers with maximum exposure to teaching-learning process. Training, on the other hand, imparts ethical values, reinforces institutional culture and maintains interpersonal relationship among employees.

Teacher Training for the Teachers of English: Due to recognition, English as an International Language, Teacher Training Programs for Teachers of English has gained due prominence all over the world. Considerable priority has been given to English Language TeacherTraining Programs. Different approaches to English Language Teacher Training and various paradigms of Teacher Training Methodology are under the discussion all over the world. With the advancement of trends in English Language Teaching Methodologies, there is more pressure on teachers of English Language than ever before. Teachers of English Language are expected to be fluent and spontaneous, hence they can teach naturally in the classroom. Stephen Krashen says that teachers of English may have both competence and performance, but theory of language teaching is different. Most of the teachers of English teach about English language, but not English language.

English Language TeacherTraining Programs are essential for 
VS Publications

Alford Council of International English \& Literature Journal(ACIELJ)

Impact Factor:4.401(SJIF)An International Peer-Reviewed English Journal

www.acielj.com

Vol-3,Issue-2,2020

ISSN:2581-6500

Teachers of English to provide effective teaching-learning models in the classroom. Teacher Training Programs should think more with regard to activities that will help develop both the pedagogical skills of the trainee and his/her language competencies (Murdoch 1994). In India, this is commonly seen that after the completion of graduation or post-graduation, the graduates come to the colleges, and universities, to join as teachers of English without getting any Teacher-Training Programs. The teachers or teaching professionals chose the profession of teaching soon after the achievement of their post-graduation credential or research degree and progress their teaching career, but they are not trained, which make them prepare and fit for the teaching profession (AICRE Report 2018). In addition, many stakeholders in the educational system believe that teachers are de-motivated by the policies of the governments, and the institutions, and they opine that they come to teaching not by choice, but by chance. Hence, there is a dire need of teachertraining for both the Teachers of English and the fresh graduates, who will soon become teachers of English to better their English language teaching.

Teacher Training for the Teachers of English at Engineering Colleges: The necessity of training for professional development of teachers of English in engineering colleges is worth mentioning. Most of the teachers of English in Engineering Colleges, while they were post-graduating, were taught but not trained. Many Engineering Colleges, recruit teachers of English, who excels at imparting knowledge of English language, but they either dearth or fall short of the trained teachers of English. In engineering colleges, Teachers of English are burdened with non-academic works. TeacherTraining Programs for bettering the quality of education was found to be a weak link. There is a dire need of limiting the clerical works assigned to the teachers (Sandhya 2018). Some Teachers of English in Engineering Colleges are unaware of contemporary trends and modern advanced techniques of ELT (English Language Teaching). Hence, Teacher-Training for teachers of English in Engineering Colleges had to be given a special consideration. Teachers should be encouraged to attend for in-service training programs. The training of educational personnel must be prioritized as the teacher is the central to change (UNESCO 1991).

In addition to, the teaching methodology of English. When a regulation is changed, needs to be improved as large numbers of students want interactive sessions to better their English language skills. The teachers of English need to be trained in communicative Language Teaching and get exposed to the challenges confronted by the professionals in several industries (Clement \& Murugavel 2015). The mere modifications and value additions to syllabus cannot be worked out to bring in a controlled output unless the teachers of English are motivated and trained to improve their teaching methodology to bridge the gap between the academics and workplace arena. 
VS Publications

Alford Council of International English \& Literature Journal(ACIELJ)

Impact Factor:4.401(SJIF)An International Peer-Reviewed English Journal

www.acielj.com

Vol-3,Issue-2 ,2020

ISSN:2581-6500

This paper surveyed on the importance of Training for Teachers of English, serving in engineering colleges by executing a questionnaire with 70 Teachers of English in various Engineering Colleges, placed across Andhra Pradesh, India. The below italicized statements are extracted from the questionnaire, executed by the teachers of English serving in Engineering Colleges. The ways teachers teach with their communication style reflect on student community. Most of the teachers are good at their subject knowledge but when it comes to delivery and explanation in front of the students in the classroom, we could find an evident gap that has to be bridged. Teacher's training is paramount important in language teaching to bridge this gap. Hence, the closed-ended statement in the questionnaire, "The Teachers of English language require special orientation/training programs to teach the syllabus prescribed by the university." is included with the "Agree, Disagree and Neutral' options. 90\% (63 out of 70) teachers supported the statement and only $5.7 \%$ (4) teachers opposed it. 4 of them stayed neutral. Hence, it is obvious that a special orientation training program is badly required.

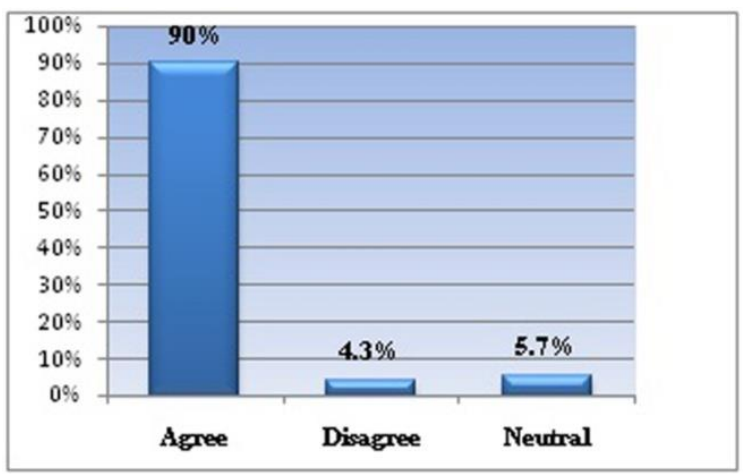

Figure -1 Training teaching prescribed syllabus
Usually for every three years, technical universities alter their regulations by including some value additions to the syllabus. Then teachers of engineering colleges, particularly language teachers, struggle a bit to acclimatize the altered syllabus. If there is a training program for the teachers when syllabus is changed or altered, it lessens the teacher burnout and helps him impart language skills effectively in the classroom. To validate this idea, in this research questionnaire, includes the closed-ended statement "The teachers require training teaching whenever there is a change in the syllabus" with 'Agree, Disagree and Neutral' options. $88.6 \%$ (62 out of 70 ) of teachers of English ratified the statement and. 5.7\% (4) of teachers opposed it and $5.7 \%$ (4) of teachers remained neutral. If teachers are trained, the teaching - learning process in the classroom is significantly effective and fruitful.

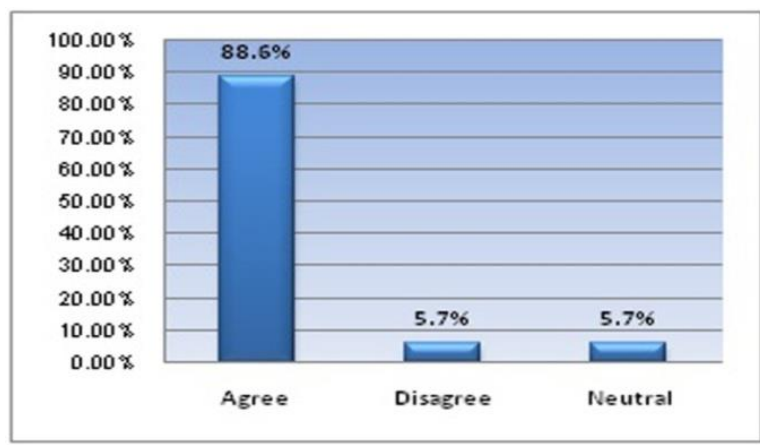

Figure -2 Training teaching syllabus, when a regulation is changed

Hence, the result of the statements determines there is a dire need for Teachers of English language to be trained to teach the engineering students. Teachers of English in Engineering Colleges have to be trained for upgrading their teaching. English Syllabus for Engineering Students 
VS Publications

Alford Council of International English \& Literature Journal(ACIELJ)

Impact Factor:4.401(SJIF)An International Peer-Reviewed English Journal

www.acielj.com

Vol-3,Issue-2,2020

ISSN:2581-6500

has been designed to make the students speak in English. All the Technical Universities design English Language syllabus based on the new methods like Task Based Language Teaching, Activity Based Language Teaching, Communicative Language Teaching, Content Based Language Teaching, Situational Language Teaching, and so on. If a Teacher of English in Engineering College wants to execute these methods successfully well, he must be trained first on the domain of expertise. The TeacherTraining promotes Teachers' teaching competency over his/her subject. Teachers' confidence in the classroom is impeded by his poor command of English language (Doff 1987). At present, the shift is on English language rather than English literature. Maximum number of teachers of English in Engineering Colleges teaches differently from what they have learnt at their graduation and post-graduation level, where they learnt literature more than the language. Hence, Training for Teachers of English in Engineering colleges plays a predominant role in shaping teaching learning process at Engineering Level. Teacher training should not be limited to the subject knowledge they deal with but to be extended to the optimum level of great human personality.

Findings: Teacher Training is strongly recommended for the teacher of English, serving in engineering colleges in two levels i.e. for teaching English language, designed by the technical Universities and to acclimatize the advanced value additions, incorporated by the universities when 'Regulations' changed.
Further Research: Only a few TeacherTraining courses are able to achieve the objective of improving the communicative command of the language rather than knowledge of it (Cullen 1994). It requires further research for what kind of 'Training Courses and Materials' suit for the teachers of English, serving in engineering colleges to fulfill the contemporary language needs of engineering students.

Conclusion: Trained teachers of English could be aware of advanced tools, emerging technologies, curriculum resources, etc... Successful English teaching-learning practices demand trained teachers with great deal of subject knowledge and teaching skills. A good Teacher-Training Program should be like a support for teachers to sharpen their tools when required (Prashar Ghildyal 2016). A good quality teacher-training and professional-development programs alongwith motivating atmosphere will have affirmative impacts on the teachinglearning development (Boudersa, Nassira 2016). The Learning Policy Institute report says that even the best trained professional may fail to produce desired outcomes, if they have barriers to like inadequate resources, lack of shared vision about what high-quality instruction entails, lack of time for planning and implementing new instructional approaches, conflicting requirements, such as scripted curriculum or pacing guides and lack of adequate foundational knowledge on the part of teachers

(www.learningpolicyinstitute.org). 
VS Publications

Alford Council of International English \& Literature Journal(ACIELJ)

Impact Factor:4.401(SJIF)An International Peer-Reviewed English Journal

www.acielj.com

Vol-3,Issue-2,2020

ISSN:2581-6500

\section{References:}

[1]Reimer, M. J. (2002), 'English and Communication Skills for the Global Engineer', Global Journal of Engineering Education, Australia, 6(1) 91-100.

[2]https://keydifferences.com/differencebetween-teaching-and-training.html [3]Richards and Farrell (2005), 'Professional Development for Language Teachers' Cambridge University Press.

[4]Rayappa, D. (2016). 'The Obstacles of Communication skills in (LSRW) faced by engineering graduates as per statistical analysis of cosmopolitan cities in India' The ELT Practitioner, A Quarterly Online Journal, English Language Teachers, Association of India (ELTAI), 3(1), 1-13. [5]Kunter, M., Baumert, J. \& Koller, O. (2007). 'Effective Classroom Management, and the Development of Subject Related Interest' Learning and Instruction, ELSEVIER, 17(5), 494-509.

[6]Boudersa, Nassira (2016). 'The Importance of Teachers, ' Training Programs, and Professional Development in the Algerian Educational Context: Toward Informed and Effective Teaching Practices' Experiences Pedagogiques, 01. [7]Prashar Ghildyal (2016). 'Good teacher good student. Reiterating the importance of teacher training' available: https://www.linkedin.com/pulse/goodteacher-student-reiterating-importancetraining-prakhar-ghildyal

[8]Emmer, E. T., \& Sabornie, E. J. (2015), Handbook of Classroom Management, Second Edition, New York: Routledge.

[9]Guerriero, S. (2016). 'Teachers' Pedagogical Knowledge, and the Teaching Profession: Background Report and Project Objectives' OCED Project, available
http://www.oecd.org/education/ceri/Backg round_document_to_Symposium_ITELFINAL.pdf

[10]Murdoch, G. (1994). 'Language development provision in teacher training curricula' ELT Journal, 48(3), 253-259.

[11]AICTE Report (2018). A Comprehensive Training policy for Technical teachers (p.5), available at: https://www.aicte-

india.org/sites/default/files/TRAINING

POLICY FOR TECHNICAL TEACHERS_BOOK (12).pdf

[12]Sandhya Sangai (2018), 'Implementation of Quality Improvement Initiatives in Madhya Pradesh, A Report, NCERT, 1-183, available at: http://www.ncert.nic.in/departments/nie/de e/publication/pdf/MP_Study.pdf

[13]Clement, A. \& Murugavel, T. (2015). 'English For Employability: A Case Study of the English Language Training Need Analysis for Engineering Students in India' English Language Teaching, Published by Canadian Center of Science and Education 8(2) 116-125.

[14]Doff, Allen. (1987). 'Training Materials as an Instrument of methodological Change," Macmillan.

[15]https://learningpolicyinstitute.org/prod ucts/reports

[16]Schrier. L. L. (1994). 'Understanding the Foreign Language Teacher Education Process," ADFL Bulletin, 69-74.

[17]UNESCO (1991). Experts' Meeting on Teacher Training and New Contents in Teacher Training Curricula, Final Report, 1-32.

[18]Cullen, R. (1994). 'Incorporating language improvement in teacher training programs' ELT Journal, 48(2), 163-171. 
VS Publications

Alford Council of International English \& Literature Journal(ACIELJ)

Impact Factor:4.401(SJIF)An International Peer-Reviewed English Journal www.acielj.com

ISSN:2581-6500

Web References:

[1]http://ip.ce.uci.edu/wpcontent/uploads/2014/11/2017-

2019-ESL.pdf

[2]https://www.esl-

languages.com/en/course-types-

for-teachers-in-english.htm

[3]http://www.differencebetween.n

et/miscellaneous/difference-

between-teaching-and-training/

[4]https://trainingindustry.com/arti

cles/workforce-

development/teaching-is-different-

from-training-how-to-use-both-

effectively/

[5]https://laringsmiljosenteret.uis.n

$\mathrm{o} /$ programmes-and- project/classroom-interaction-for-

enhanced-student-learning-

ciesl/news/importance-of-teacher-

learning-for-students-achievementarticle121594-22147.html

[7]https://www.cambridgeenglish.o $\mathrm{rg}$

[8]https://www.britishcouncil.pl/sit es/default/files/delta_syllabus_201 5.pdf

[9]https://www.bgsu.edu/arts-andsciences/english/english-forspeakers-of-other-languages.html [10]https://www.cambridgeenglish. org/Images/272246-coursecertificate-in-celt-p-overview.pdf 